\title{
Gain of Chromosome 9
}

National Cancer Institute

\section{Source}

National Cancer Institute. Gain of Chromosome 9. NCI Thesaurus. Code C36463.

A cytogenetic abnormality that refers to the allelic gain of all or part of chromosome 9 . 